\title{
Competitiveness and Determinants of Coffee Export in Ethiopia: An Analysis of Revealed Comparative Advantage and Autoregressive Distributed Lag Model
}

\author{
Diriba Hordofa Jalata \\ Ethiopia Coffee and Tea Authority, Market Data Analysis and Dissemination Expert \\ Mexico Square, Addis Ababa, Ethiopia, P.O.Box 5131
}

\begin{abstract}
As an export commodity coffee industry contributes to the economies of both exporting and importing countries. The aim of study involves competitiveness and determinant of coffee export in Ethiopia through the period of 1990-2018 observations. To explain level of comparative advantage and competitiveness respectively Revealed Comparative Advantage and Syematric Revealed Comparative Advantage were employed. To capture determinans of coffee ARDL model with bound testing to co-integration approach was employed to investigate the long run association between Ethiopian total coffee export in bags (60kg each) with domestic coffee production, world coffe price,real exchange rate,FDI,world coffee production and price ratio. Eventhough Ethiopia has comparative advantage in export of coffee however, the share it in international market low in amount and not in lined with RCA. Bound testing to co-integration approach result confirmed the existence of a long-run relationship between total coffee exports of Ethiopian with its independent variables. The analysis pointed out that in the long run the extent of domestic coffee production, world price and real exchange rate positively and significantly affects total coffee export. However, FDI, price ration, world production of coffee have negative \& significant effect. In short run Ethiopian total coffee export defined as positive significant function of domestic coffee production and real exchange rate positive but insignificant effect with Level of RCA and world price as well as negative function of FDI, price ration and world production of coffee. Evidence from Granger causality test confirms that unidirectional,bidirectional and independent Granger causality were observed. Coefficient Error Correction Model (ECM (-1)) was negative and significant with value $134.4 \%$ of the adjustment would made each year and returned to its long-run equilibrium after 1.3 years. The policy implication calls for addressing issues of combined effect of the policy setting, institutions and market failures to avoid evil effect of the sector.
\end{abstract}

Keywords: ARDL Coffee Competitiveness Determinant RCA

DOI: $10.7176 / \mathrm{JESD} / 12-5-05$

Publication date:March $31^{\text {st }} 2021$

\section{INTRODUCTION}

Major concern for developed and developing countries is to gain and sustain high economic growth and development. To achieve this, exports signify primary sources of foreign exchange i.e. encourage the balance of payments and create employments opportunities (Raheem, 2016). While an increase in the size of international trade, the concept of export competitiveness also plays a significant effect in the international trading system. Bruneckiene and Paltanavicience (2012) cited in Sachitra (n.d) point out that; international competitiveness often identified and inclined with exports. Subsequently, as an export commodity coffee industry contributes to the economies of both exporting and importing countries. Coffee one of the world's most widely traded commodities (Handal, 2014) i.e. ranks second most traded primary-commodity next to crude oil in the world (UNCTD, 2018). It is a globally competitive and marketed commodity,brings happiness and social value around the world (ICO, 2019). Worldwide coffee production varieties is divided to approximately $80 \%$ in favor of Arabica and around $20 \%$ is Robusta (Zekarias \& Degye,2019). According to ICO (2019), coffee is the main livelihood for up to 25 million households; farmed in more than 70 countries of which $20 \%$ of them ranked $(\mathrm{HDI}<0.5)$ including Ethiopia with HDI of 0.463 (FAO, 2019), source of income for more than 12 million farmers; quarter of which operated by women and $70 \%$ of total production exported. In addition to this, due to recent waning up of coffee production in some major producing countries, the rate of world coffee production growth trend comparatively tends to decrease than before in parallel with the growth rate of world coffee consumption (Rosiana et.al, 2017).

Ethiopia's export sector dominated by export of few primary commodities with agricultural products mainly coffee, oilseeds, gold, chat, flower, pulses, live animals, and hide skins. The coffee subsector is a black box of Ethiopian export earnings and plays an important role in the economy of the rural population. According to CSA in the period of 2003/4 to 2017/18 data, total area coverage of coffee is 1.2 million hectares of which 900,000 hectares of land is estimated to be productive of which about $92-95 \%$ produced by 4.7 million small scale farmers and the rest 5-8\% large scale plantations. Moreover, about 25 million people are engaged in the coffee transaction; about 5.27 million households participated in coffee production with an estimated annual production of 500,000700,000 tons of which $50 \%$ estimated to be consumed locally. On average national productivity estimated to 7 
quintals per hectare. Alemayehu (2014) summarize in Ethiopians coffee contributes $25 \%-30 \%$ of the country's foreign exchange, $5 \%$ of GDP, $90 \%$ of total exports, $85 \%$ of total employment in the country, and part of the culture; about $50 \%$ of the produced coffee is consumed domestically. However,ICO (2017) examined prospect for the African Arabica coffee sector put forward that Ethiopia, has largely stagnated in recent years.

FAS (2018) showed that, Ethiopia is the native land of coffee Arabica. Habtamu (2019) not only for being the home of Arabica coffee but also well known for its very fine quality coffee praised for its aroma and flavor characteristics. However, Ahmed et.al. (2018) improvement of value addition activities has to be give due attention on policy makers and actors in the production system as the recent remedial measure diversification of trade from primary agricultural commodities into high-value commodities.

Analysis of competitiveness and comparative advantage of a given export commodity is also a decisive effect on the progressive economic growth of a nation (Kebede, n.d). On the other hand, the concept of comparative advantage, Tjondro et.al (2018) stated that a strength or weakness of competitiveness of a country is caused by expansion of business areas, business efficiency, natural disasters, human resource capabilities, and climate/weather.As a result, the competitiveness of the country's economy is a key economic policy priority. Conceptually, Latruffe (2010) competitiveness is defined as the capacity of a country (in this case Ethiopia) to bid products (coffee in this circumstance) and services that meet local and international quality standards, value domestic and global market prices and provide adequate returns on the resources used in producing them. Thus, complete measuring the export level of a country's commodity (coffee in this case) in the global market concerning the share of the respective country's export competitiveness in world exports by assuming that the international competitiveness, rather than demand in a foreign market, that leads to an increase in export share (Kim, 2019). Yet, internal demand in the process of making local consumption not ignored Soressa (2013) while explaining international competitiveness. However, given the comparative advantage in marketing and the potential to achieve trade gains that the country possesses, the benefit from the coffee sub-sector in facts and data indicated far below its potential. Consequently, coffee product export as the black box of the country needs the study to judge this type of continuous waning up. Studies for example (Teshome, 2009: Hassen,2015: Wondesen \& Fekadu, 2019: Zekarias \& Degye,2019) analyzed the impact of various variables like the amount of rainfall in millimeter (climatic resource) \& Agricultural labor employed in man-days, Institutions \& populations on the export performance of coffee in their studies. However, World Bank (2014) Ethiopia has a high potential (comparative advantage) to expand or upgrade export sectors where the core competencies (land, labor, capital, and institutions).

Keeping in view, all most none of the studies has incorporated the level of comparative advantage of the country in producing and exporting this product as one variable in their study model. Thus,broadly speaking,with these background the purpose of this study is to analysis competitiveness and major determinants of total coffee export in Ethiopia with definite objective to explain competitiveness and its implication of coffee export in Ethiopia and to assess the major determinants of coffee export in Ethiopia. Moreover, in the total coffee export sector, and tries to address issues that enhance the total coffee export growth and to make that growth sustainable, competitive in the international markets, and eventually maximize the benefit that earned from the coffee sector

\section{Literature Review}

Analyzing the export performance of the coffee sub-sector with a special focus on competitiveness and the determinants coffee export had attracted the attention of both policy makers and researchers in different parts of the world, particularly in developing countries. Hence, then given Ethiopia's endowment of natural resources and other competitive advantages the export of coffee products provides a good opportunity to diversify the export base which are mainly dependent on exports of agricultural products.

As the determinansts of coffee, competitive advantage is strongly related to external and internal factors and. Thus, Porter's Diamond approach offers four criteria to measure the level competitiveness which widely used in many literatures to assess the possibility of competitiveness at the country level Arpine (2018) which is an epicenter of this study with one commodity. However, competitiveness analyzed at region level (within the country) Hailay (2018), region/bloc level Fojtikova (2016) discussed in Martin \& Tomas (2019) and industry level Atilla et.al (2017).

Yee et al. (2016) emperically validated the Marshall Learner hypothesis by examining a determinants of export in Malaysia with time series from 1975 to 2013 years using OLS. The result reveal that there is positive significant relationship with variable real exchange rate and Malaysian export performance which is supported by many scholars (David and Christian, 2013: Boansi et.al,2014:Sawore,2015:NBE,2017:Ahmed et.al,2018). However, some studies such as (Alelign,2014:Hassen,2015:Abolagba et.al,2016:Monineath,2018) autonomously shows how real exchange rate has negative significant effect on export performance. Controversial results of Tadese (2015) found insignificant result both in the long run and short run. Correspondingly, the findings of (Yisak,2009:Manji,2010: Alekaw,2014) while explaining the export performance of Ethiopia an influence real exchange rate is insignificant or weak significance.

Since it is motivated by comparative advantage of the host country there is a concessions among development 
economists that FDI inflows are likely to play an important role in explaining growth of many recipient countries UNCTAD (2018) report. To express, (David \& Christian,2013:Bhavan,2016:Ahmed et.al,2018:Özgur \& Abdulakadir,2018 and Bihonegn \& Kurabachew,2018) indicates how FDI positively and significantly affects export performance.Antagonistically, (Yisak,2009:Manji,2010:Kiros,2012:Tigist,2018) scrutinized determinants of export performance and came up with result insignificant or indistinguishable effect of FDI on export performance in Ethiopia. Hence then,empirical analysis of Boansi (2014) shows and summarizes that, due to the fact that such type of investment depends on its motive, whereby export-oriented FDI will promote the export performance of the exported commodities as the result foreign direct investment (FDI) have an inverse relationship with export performance.

Muhammad et.al, (2018) comparatively investigates coffee export dynamics in Indonesia a based on monthly data starting from September 2010 to December 2015 by using the vector error correction model (VECM). The result of this finding forwarded the argument that, international coffee price in the long run positively and significantly impacts volume of Indonesian coffee exports consistent with (Samuel,2012:Ahmed et.al,2018:Gebretsadik,2018) but against with (Netsanet,2016). Muhammad et.al on the same study also showed that, impulse response of each variable produce a sharp shock at the beginning of the period but would reach a stable at the end of the period where variance decomposition, affects the variable itself and there is a significant contribution given by international coffee price and the exchange rate variables over time.

Hussain et.al. (2020) examined study and investigation on the impact of supply-side factors on the export performance of Pakistan with time-series data set of from 1971 to 2014 using Autoregressive Distributed Lag (ARDL) model (bound testing approach). The empirical analysis of this finding reveals that domestic production capacity is positively and significantly influence primary export performance both in short run and long run. This result was analogous to (Belayneh \& Wondaferahu,2012:Boansi,2013:Boansi et.al,2014:Tadesse,2015:Abolagbaet.al,2016)deep-rooted positive significant relationship between domestic production and export performance.

Zekarias \& Degye (2019) due to long gestation period in production system and fear of continuous low price for domestic producers hence, came up with debatable result by showing increase in domestic production decrease volume coffee export in Ethiopia. David and Christian (2013) also put forwarded that since Ethiopia is not the only producer but also major consumer in Africa to overcome total coffee export domestic production would increase more than the rates at which domestic consumption would raise. The Authors also examine competitiveness and determinants of co ee exports, producer price, and production for Ethiopia in the year 1961 to 2010 using RCA and OLS. The finding confirmed that the effect of price ratio (world price to domestic producer price), has a positive significant effect on export performance of coffee export form Ethiopia.

Zekarias \& Degye (2019) on their findings of determinants of coffee export in Ethiopia displayed that supply of coffee by other producers countries could once more decrease volume coffee export in Ethiopia both in the long run and short run resembled with Tadese (2015). Hassen (2015) found error correction modeling to examine determinants of coffee export supply in Ethiopia in the Period of 1965 to 2005 result shows the fact that, real exchange rate and FDI granger cause's coffee export supply in Ethiopia. Keeping other things constant Tadesse (2015) also illustrates granger causal effect that follows from domestic coffee production to export supply of coffee. Bihonegn and Kurabachew (2018) also estimates and indicate that a greater proportion of the variation in total value of major export of Ethiopia is due to its own innovations whereas a one standard deviation shock originating from the other variables at initial period do not have any impact on major export commodities and responds positively to its shocks.

\section{Conceptual Framework}

The measurement and study of the competitiveness and determinants of coffee export performance has evolved significantly departs from above literature in two dimensions. First, from methodological point of view explicitly,contemporary study of most researchers in investigating determinants of coffee export in Ethiopia like (David and Christian,2013:Tadese,2015:Hassen,2015:Gebretsadik,2018 and Zekarias \& Degye,2019) emphasized the use of OLS, co-integration, error correction and dynamic gravity modeling technique for estimation of export demand and supply functions.However, keeping in view these problems, due to different rationale behind the the study uses the autoregressive distributed lag (ARDL) model as seen in (Pesaran, Shin, \& Smith, 2001) to analyze and capture determinant of coffee. The other dimension, many strands of the literature combine international trade theories with those of macro-level competitiveness, argues that the competitiveness of nations can be interpreted, and measured via trade based indices called Balassa (1965) or Balass Index which is considered to be one of the most outstanding and useful methods of assessment of a nation's competitiveness which is the epicenter of this paper. 


\section{METHODOLOGY OF THE STUDY}

\subsection{Type and Source of Data}

Accordingly, time series secondary datum obtained from National Bank of Ethiopia (NBE), International Coffee Organization (ICO), and United Nation Statistical Division (UNSD) of Commodity Trade (COMTRADE) Data Base, United Nation Food and Agriculture Organization Statistics (UN-FAOSTAT) were used.

\subsection{Model Specification}

The theoretical framework of competitiveness probably shows the most eminent index analyzing export competitiveness of nations is Revealed Comparative Advantage (RCA). Revealed Comparative Advantage (RCA) proposed by Bela Balassa and known as Balassa Index. Balassa's $(1979,1986)$ has come out with the RCA index that compares the export of a given strong sector in a country with the export share of that sector in the world market. Among them Revealed Comparative Advantage (RCA) and the Revealed Symmetric Comparative Advantage (as an index of competitiveness) Nwachuku et.al (2010) mentioned in Verter (2016). Competitiveness measured by RCA is denoted the primary competitiveness, measured by comparative advantage hence, if the product described as competitive, it means that it has a revealed comparative advantage.

Revealed Comparative Advantage (RCA): The idea to determine a country's 'strong' sectors like coffee sector in Ethiopia by analyzing the actual export flows pioneered by Liesner (1958). Since the procedure refined and popularized by Balassa $(1965,1989)$ it has popularly known as the Balassa Index. ITC (2016) points out that Revealed Comparative Advantage of a specific country in the trade of a given industry's products measures the industry's share in the country's exports relative to the share in world trade. More specifically, if $B I_{j}^{A}$ is country $A$ 's Balassa index is normalized export share for industry $j$, defined as to:

$$
B I^{A} J=\frac{\text { Share industry } J \text { in country A export }}{\text { share industry } J \text { in reference country export }} \ldots \ldots \ldots \ldots \ldots \ldots .1
$$

If $B I^{A}{ }_{j}>$ one, country $A$ is said to have a revealed comparative advantage in industry $j$, since this industry is more important for country $A$ 's exports than for the exports of the reference countries. Upon the above estimation method Ethiopian coffee export RCA estimated as follows:

$$
\boldsymbol{R C A t}=\frac{\text { coffee export of Ethiopia }(t) / \text { agricultural export of Ethiopia }(t)}{\text { world coffee export }(t) / \text { world agricultural export }(t)} \ldots 3.2
$$

Where: $t$ is time in a year. The RCA index takes values between zero and $+\infty$. If it takes a value less than or equal to 1 , that country may have not specialized in exporting that product while if the index takes a value more than 1 , this implies that the country is specialized in exporting that product (ITC, 2016). Hinloopen (2001) mentioned in (Birol \& Kasim, 2014) Purposed further divide revealed comparative advantage into four as follows:

Classification $1 \rightarrow 0<\mathrm{RCA} \leq 1$; There is no comparative advantage.

Classification $2 \rightarrow 1<\mathrm{RCA} \leq 2$; There is a week comparative advantage.

Classification $3 \rightarrow 2<\mathrm{RCA} \leq 4$; There is moderate comparative advantage.

Classification $4 \rightarrow 4<\mathrm{RCA}$; There is a strong comparative advantage

Revealed Symmetric Comparative Advantage (RSCA): The Revealed Symmetric Comparative Advantage measures and reflects the RCA in its symmetric form as an index of competitiveness. Computation is follows:

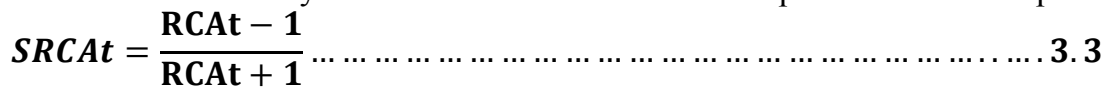

Where: $t$ is the time in a year. Laursen (1998) put forward that, the value of SRCA ranges from minus one to a positive one. It assumes the closer the value is to plus one, the higher the competitiveness of a country in the commodity of interest (coffee here) and vise-versa.

\subsection{Theoretical framework model for the determinants of coffee export}

The model used in this paper is adopted from Goldstein and Khan (1985) imperfect substitution model. According to imperfect substitutes model export supply traditionally depends on the real export prices, real exchange rate, and productive capacity. Consequently, the general form of the export supply function expressed as:

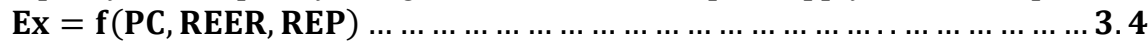

Where $E_{x}$ represents the volume of exports, REP is a real export price, REER is real exchange rate, and $P_{C}$ is the capacity of production.

\subsection{Econometric model specification for the determinant of export}

The study initiated to prudently identifying both demand and supply-side factors that is explaining export behavior of Ethiopia. A log-linear function used to determine Ethiopia's total coffee export performance for the reason that it fits the model based on having the highest number of significant variables affecting coffee export which is analogous to (Belayneh \& Wondaferahu,2012:Tadesse,2015 and Ahmed et.al,2018) in analyzing export performance sector in Ethiopia. Thus, squeezing the estimated coefficients of each regressor in the model, the total coffee export model employed by considering the effect of other stochastic factors that not controlled in the model 
and by the model econometrically specified, as single equation 3.5 below would, captures the determinants of total coffee export in Ethiopia.

$T C E=\alpha+\beta 1 R E R+\beta 2 W p d+\beta 3 D p d+\beta 4 C p r+\beta 5 W p r+\beta 6 F D I+\beta 7 R C A+\varepsilon i)-----3.5$

The magnitude and coefficient of each variable as well as the effects of key determinants on total coffee export were identified and empirically analyzed with time series which covers from 1990 to 2018 to identify short-run and long-run effects on the dependent variable. Except price ratio in relative form and level of comparative advantage which is a dummy variable all variables entered to model in natural logarithm form.

\section{LnTCE $=\alpha+\beta 1 L n R E R t+\beta 2 L n F D I t+\beta 3 L n W p r t+\beta 4 L n D p d t+\beta 5 C p r t+\beta 6 L n W p d t$$$
+\beta 7 R C A t+\varepsilon i)--3.6
$$

Where: LnTCEt=Logarithm of total coffee export in year $t, \mathbf{L n F D I t}=$ Logarithm of FDI in year $t$ LnRERt=Logarithm of real exchange rate in year $t, \mathbf{L n W p r t}=$ Logarithm of annual average world coffee price in year t,LnDpdt $=$ Logarithm of domestic production of coffee in year $t, \mathbf{C p r t}=$ Coffee price ratio in year $\mathrm{t}, \mathbf{L n W p d t}=$ Logarithm of world production in year t, RCAt $=$ dummy: index of comparative advantage in year t. $\beta 1 \ldots . . \beta 8=$ Coefficients to be estimated,

$\mathrm{Ln}=$ Natural logarithm $\varepsilon \mathrm{i}=$ Stochastic error term $: \alpha=$ constant term: Estimation and analyzed using Eviews Version 10 (IHS Global Inc.Englewood, CO, USA).

Variables Definition and Description:Total coffee export (LnTCEt): The study uses the amount of coffee exported or supplied to all destinations measured in bags (60kg each) at time $\boldsymbol{t}$ in $\log$ form be considered as the dependent variable with independent Variables:

Real exchange rate $\left(\boldsymbol{L n R E R I}{ }^{+}\right)$:Exchange rate is the rate at which one currency (ETB) exchanged for another currency (USD) at the world current currency exchange rate. $\boldsymbol{R} \boldsymbol{E} \boldsymbol{R}=\boldsymbol{E} \frac{\boldsymbol{P} *}{\boldsymbol{P}}$. Where $\mathrm{E}$ is the nominal exchange rates expressed in local currency (ETB) against the USD, $\mathrm{P}^{*}$ is the foreign price in USD of the major Ethiopian exports (coffee in this case) and $\mathrm{P}$ is the Ethiopia consumer price index. The real exchange rate is also a measure of real competitiveness, as it captures the relative prices, costs, and productivity of one particular country concerning the rest of the world (Auboin \& Ruta, 2011).

Foreign direct investment( $\left.\mathbf{L n F D I}{ }^{+}\right)$: FDI is another important factor affecting the export supply capacity of a country (UNCTAD, 2018) and it represents foreign direct investment stock in Ethiopia (in USD million) at time t. World coffee price (LnWprt ${ }^{+}$): The paper captured as the average annual value both Arabica and Robusta ICO indicators measured by US cents per pound.

Total domestic production of coffee $\left(\operatorname{LnDpd}_{t}^{+}\right)$: In this study, total domestic production of coffee is the total amount of green coffee beans produced domestically. To being the prevailing truth and make this paper kind it is obtained from ICO as an estimate of the total coffee production for Ethiopia and measured in bags $(60 \mathrm{~kg}$ each)

Coffee price ratio (Cprt $\left.{ }^{+-}\right)$: This would have apprehended as in Boansi et.al (2014) and Boansi \& Crentsil (2013) the relative price of annual average coffee price to domestic producer price as price ration used as an explanatory variable here.Therefore, price ratio as a proxy foreign price of coffee to producer price of coffee given at period (t) used as an index obtained from ICO for foreign coffee price \& FAOSTAT for domestic coffee producer prices on an annual average basis.

World coffee production $\left(\boldsymbol{L n} \boldsymbol{W} \boldsymbol{p d} \boldsymbol{d}^{-}\right)$: This can be the amount of coffee produced worldwide by the top ten (81.23\%) coffee producing and exporting countries measured in bags (60kg each).

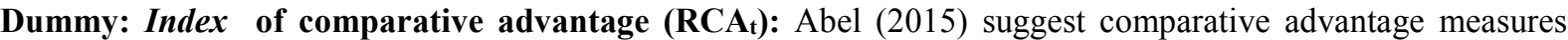
determinant of trade pattern, which leads the international trade specialization and determined by several supply and demand factors. As a result, the comparative advantage would be entered into the model as a dummy variable not in $\log$ form as fixed regressor analogous to Ahmed et.al (2018). Hence, in this case, one= for Strong comparative advantage otherwise zero for weak comparative advantage obtained and depending on index RCA values acquired on equation (3.2) above.

\subsection{ARDL Model Fitting \& Estimation Procedures}

Autoregressive Distributed Lag (ARDL) Co-integration Bound Testing introduced by Pesaran, Shin, and Smith (1996), Pesaran and Smith (1999) whereas Pesaran et.al (2001) develops it further. This approach has a lot of econometric advantages as compared to other techniques; it can be used when variables stationary. Second, it uses an optimum number of lags in Data Generating Process (DGP) or allows each variables in the model may have different optimal lag length. Third, it gives strong and consistent results in a small sample size.Fourth, it deals with endogeneity problems (Pesaran and Shin, 1999; Pesaran et al., 2001). Further, according to Bentzen and Engsted, (2001) it runs simultaneously long run and short-run effects on one variable to another variable.

\subsubsection{Stationary tests (Unit root test)}

Some of the most efficient ways of testing for the presence of stationarity concerning time series model is the application of the Augmented Dickey-Fuller (ADF) after Dickey \& Fuller (1979) and Phillip-Perron (PP) after (Phillips \& Perron, 1988) test. The decision rule based on failure to reject the null hypothesis of no random walk 
when all variables are stationary of the order level; otherwise, we fail to reject the null hypothesis, which thus leads to the test for stationarity.

\subsubsection{Lag length determinations}

According to Pesaran et al. (2001) the lag selection is the second step for the autoregressive distributive lag (ARDL) model. This means in the case of Ethiopian coffee sector, coffee export in one period may depend on the surplus production made by the production factors in the previous period. This period or laps of time in econometrics called lag. Thus, the ARDL model employs the optimum lag of dependent and explanatory variables using Akaike Information Criterion (AIC), Schwarz, and Hannan Quinn information criteria.

\subsubsection{ARDL bounds testing}

The use Bounds testing technique's is established on three justifications. Firstly, Pesaran et al. (2001) encouraged the use of the ARDL model for the estimation of level relationships because the model suggests that if the order of the ARDL has been identified, the relationship may be estimated by OLS method. Secondly, the bounds test for co-integration permits a mixture of I (1) and I (0) variables as regressors. In other words, the order of integration of appropriate variables may not necessarily be the same hence the ARDL technique has the advantage of not requiring a specific identification of the order of the underlying data. Thirdly, bound test is based on the ARDL model and gilded by the assumption that the variables are stationary at level I (0) and the first difference I (1) and hence, none of the variables was stationary at the second difference I (2). The basic form of an ARDL (p, q) regression model given by:

$$
T C E t=\beta 0+\beta 1 T C E-1+\ldots+\beta k T C E T-P+\alpha X t+\alpha 1 X t-1+\ldots+\alpha q X t-q+\epsilon t \ldots \ldots .1 .10
$$

Equation 3.10 represented the Autoregressive Distributed Lag (ARDL) version as in the equation 3.11 below. Where the constants is $\alpha$ and coefficients were $\alpha \mathbf{1}=\alpha \mathbf{2}=\alpha \mathbf{3}=\alpha \mathbf{4}=\alpha \mathbf{5}=\alpha 6=\alpha 7$ and $\boldsymbol{\beta} \mathbf{1}=\boldsymbol{\beta} \mathbf{2}=\boldsymbol{\beta} \mathbf{3}=\boldsymbol{\beta} \mathbf{4}=$ $\boldsymbol{\beta} \mathbf{6}=\boldsymbol{\beta} 7$ represent lagged dependent and independent variables respectively. $\boldsymbol{\epsilon}$ Error term and $\mathbf{p}$ represent the maximum lag length of dependent variable $\mathbf{q}$ was maximum lag length independent variables $e . i$ decided by the lag selection criteria. There were two procedures for testing co-integration relationship between total coffee export and the independent variables. The first procedure was to estimate eq. (3.11) by OLS procedure as Pesaran et al. (2001). Secondly, the existence of co-integration traced by restricting all estimated coefficients of lagged level variables equal to zero as shown below.

$$
\begin{aligned}
& \Delta \log T C E t=\alpha 0+\sum_{I=1}^{P} \beta 1 \Delta \log T C E t_{-i}+\sum_{i=0}^{q} \beta 2 \Delta \log R E R t_{-i}+\sum_{i=0}^{q} \beta 3 L n F D I t_{-} i+\sum_{i=0}^{q} \beta 4 \Delta \text { LnWprt } i \\
& +\sum_{i=0}^{q} \beta 5 C p r t_{-} i+\sum_{i=0}^{q} \beta 6 \Delta \ln \quad D p d t_{-i}+\sum_{i=0}^{q} \beta 7 \Delta \ln \sum_{i=0}^{q} \beta 8 \Delta R C A t_{-i}+\alpha 1 \ln T C E t_{-i} \\
& +\alpha 2{\ln R E R t_{-i}+\alpha 3 \text { LnFDIt }_{-}+\alpha 4 \ln \text { Wprt }_{-i}+\alpha 5 \ln C p r t_{-i}} \\
& +\alpha 6 \ln D p d t_{-i}+\alpha 7 \ln W p d t_{-i}+\alpha 8 R C A t_{-i}
\end{aligned}
$$

The bounds testing procedure requires the estimation of the above equation. In the ARDL bounds test of cointegration, F-statistics was used to examine the null hypothesis of no co-integration among the variables. The null and alternative hypotheses are as follows:H0: $\alpha \mathbf{1}=\alpha \mathbf{2}=\alpha \mathbf{3}=\alpha \mathbf{4}=\alpha \mathbf{5}=\alpha \mathbf{6}=\alpha \mathbf{7}=\mathbf{0}$ (no long-run relationship) Against the alternative hypothesis, H1: $\alpha \mathbf{1} \neq \alpha \mathbf{2} \neq \alpha \mathbf{3} \neq \alpha \mathbf{4} \neq \alpha \mathbf{5} \neq \alpha \mathbf{6} \neq \alpha \mathbf{7} \neq \mathbf{0}$ (a long-run relationship exists). According to Pesaran et.al. (2001) for decision rule ARDL bounds test, the estimated F-statistics value compared with the two sets of critical values of the upper- and lower bounds. If the estimated F-statistics value is higher than the upper bound critical values, then the null hypothesis of no co-integration rejected. If it lies between the two critical values, the conclusion is indecisive. If the value of F-statistics is lower than the lower bound critical values, the null hypothesis of no co-integration not rejected.

\subsubsection{Co-integration test and error correction model}

According to EVIEWS version 10 manual II, the co-integration term is known as the error correction term since the deviation from long-run equilibrium is corrected gradually through a series of partial short-run adjustments. Alemayehu, et.al (2009) noted, the co-integration test shows that even though the variables taken separately are not stationary, i.e. are I (1) their linear combination may be stationary. Once co-integration is established, the second step involves estimating the long run ARDL model Adeniyi (2014) for dependent variable total coffee export (TCE) in this case. The conventional co-integration procedures estimate the long-run relationships within a context of system equations. 


$$
\begin{aligned}
\operatorname{lnTCE}=\alpha 0+\sum_{i=1}^{p} & \beta 1 \text { LOG TCE }_{-1} \\
& +\sum_{i=0}^{p} \beta 2 \text { LOG RERt }_{-i} \\
& +\sum_{i=0}^{p} \beta 3 \text { LnFDI }_{-i}+\sum_{i=0}^{p} \beta 4 \operatorname{LnWpdt}_{-i}+\sum_{i=0}^{p} \beta 5 C p r t_{-i} \\
& +\sum_{i=0}^{p} \beta 6 \operatorname{LnDpdt}_{-i}+\sum_{i=0}^{p} \beta 7 \operatorname{LnWprt} t_{-i}+\sum_{i=0}^{p} \beta 8 R C A t_{-i}+\epsilon t
\end{aligned}
$$

The final step involves estimating an Error Correction Model (ECM) which is representation of long run term as derived from Eq. 3.13 to obtain the short-run dynamic parameters as specified below. ECM tells us how much time it takes to adjust this short-run shock. Ecmt-1 = the error correction mechanism lagged for one period $\delta=$ the coefficients for measuring the speed of adjustment is the coefficient of the error (or equilibrium) correction term (ECT) or it is called adjustment coefficient. It shows how much of the equilibrium error is corrected each year. The error correction term indicates the speed of adjustment due to any short-run disequilibrium after a shock adjustment (Monineath, 2018).

$$
\begin{aligned}
& \Delta T C E=\alpha 0+\sum_{i=1}^{p} * \beta 1 \Delta l n \quad T C E t_{-i} \\
& +\sum_{\substack{i=0 \\
p}}^{p} \beta 2 \Delta R E R t_{-i} \\
& +\sum_{i=0}^{p} \beta 3 \Delta \ln \quad \operatorname{Cprt}_{-i}+\sum_{i=0}^{p} \beta 4 \text { Wprt }_{-i}+\sum_{i=0}^{p} \beta 5 \operatorname{lnFDIt} t_{-i} \\
& +\sum_{i=0}^{p} \beta 6 \ln \quad D p d t_{-i}+\sum_{i=0}^{p} \beta 7 \ln \quad \text { Wprt }_{-i}+\sum_{i=0}^{p} \beta 8 R C A t_{-} i++\delta E C M t_{-i}
\end{aligned}
$$

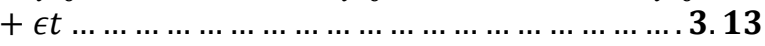

In this case a positive ECM coefficient indicates a divergence, while a negative coefficient indicates convergence and a zero ECM coefficient shows that there is no adjustment, and to claim that there is a long-run relationship does not make sense any more.

\section{RESULT AND DISCUSSION}

\subsection{Global Export and Import of Coffee}

International trade theory convinces the benefits of liberal trade in which the principal objective of any theory of international trade is to explain the cause and pattern of trade. Thus, in global coffee development scenario over $90 \%$ of green coffee production and exports take place in developing countries and so as to answer why nations trade. As the result of factor abundance theory coffee principally produced in Latin American countries like Brazil, Columbia, Peru, Honduras, and Guatemala accounts (52.13\%) in addition to African countries such as Ethiopia, Uganda (6.5\%) together with Asian countries like Vietnam, Indonesia and India (22.56\%). 


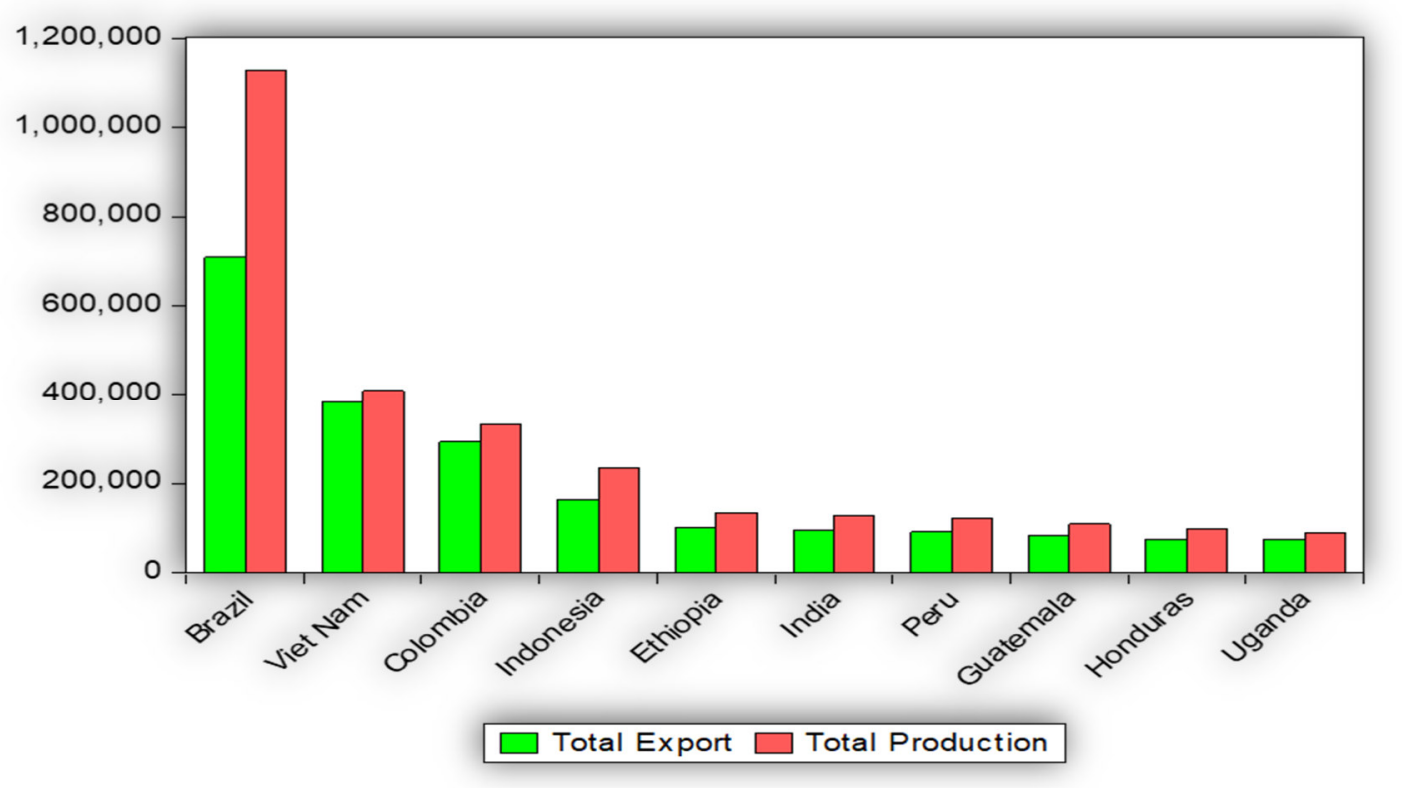

Figure 1: Global production \& export of Coffee Source: Own Computation Annual ICO Data (2020)

Moreover, in global coffee export $81.12 \%$ of total coffee export is accounted by top 10 coffee- exporting countries. For the crop year of 2018-19, world total coffee exported was 2.67 million bags (60kg each), of which Brazil ranked highest, accounting for $27.81 \%$ of global coffee export, followed by Vietnam (14.98\%), Columbia $(11.52 \%)$, Indonesia (6.41\%), Guatemala (3.94\%), India (3.72\%), Honduras (3.57), Uganda (3.31\%), Ethiopia $(2.92 \%) \&$ Peru $(2.92 \%)$ respectively (Figure 2).Domestic share of coffee exports varies across countries, for instance, Brazil, Vietnam, and Colombia, the three largest coffee-producing countries, however, they show relatively low dependence on coffee exports or they had diversified export portfolio of which $3 \%, 2 \%$, and $6 \%$ share respectively relative their annual production. whereas a country with least diversified ${ }^{1}$ export portfolio or one product dependency Honduras and Ethiopia, their share exceeds $20 \%$ to ensure how much Ethiopia highly dependent on coffee exports for its foreign currency earning. As a result, the growth of the export share of Ethiopia in international market depends on the value and volume of total coffee exports of a country regardless of the share of this agricultural export in the world market is still low around 0.0013 percent in 2016/17 crop year (WTO, 2017).

Thus, this finding agreed that,trade with low-cost through abundant labor and natural resources, although necessary, but then not enough to maintain competitiveness. This call for innovation and technological upgrading were an important to maintain competitiveness on a continuous basis by increasing value addition rather coffee beans export. In theory, trade would occur due to differences between countries i.e. trade between countries with similar relative factor endowments and trade with similar products (Krugman et al., 2012) however, trade with similar relative factor endowments is difficulty or slight insignificant Zewdu \& Minyahil (2017) in achieving the comparative advantage. Thus, in global, scenario trade patterns for green coffee exports can flow from developing countries to industrialized countries due to traditional trade theories of factor endowment $(\mathrm{H}-\mathrm{O})$ theory. Accordingly, countries exporting coffee product had the highest comparative advantages or more efficient, while diversification $^{2}$ on the export of other products have not proved to be beneficial for these countries. Yet, in theories, such as those of (Linder and Krugman, 1998) imply that trade may increasingly take place between countries of similar income levels. However, in this findings coffee export and import with similar income level is slight insignificant.

\subsection{Competitiveness of Ethiopian Coffee Export and Its Implications}

Export competitiveness of global coffee traders analyzed by the original Balassa index among different Balassabased indices described in the methodology section of this paper.Thus, the result of competitiveness index analyzed the competitiveness of coffee according to the coffee export in major top ten (81.12\%) as shown in Figure 2.This research applied the method of Revealed Comparative Advantage (RCA) level of comparative advantage

\footnotetext{
${ }^{1}$ HHI-Hirschman Herfindahl Index- Provide information on the country with a perfectly diversified export portfolio would have an index close to zero, Arpine (2018) whereas a country which exports only one export would have a value of 1 (least diversified).

${ }^{2}$ The concept diversification here, which is important especially for LDC with few primary commodities dependency for their export earnings, which may be shocked by unstable prices for these commodities may cause serious trade problem referred Arpine (2018). Thus, diversification viewed as a positive development.
} 
of each country specifically Ethiopia and Symmetric Revealed Comparative Advantage SRCA to analyze Ethiopia competitiveness and its implication. Thus, a change in competitiveness can affect the change in the export market position of a country in the given period.

\section{Revealed comparative advantage and symmetric revealed comparative advantage}

The higher the comparative advantage of a specific product, the higher the possibility of a country as a net exporter becomes Widodo (2010) cited in (Rosianal et.al, 2017). Thus, the Balassa index is considered to be one of the most outstanding and useful methods of the assessment of a nation's competitiveness. This was measured using Revealed Comparative Advantage (RCA) in which Comparative advantage of world coffee was analyzed in the form of beans (not roasted, not decaffeinated) with HS code: 090111, Based on Table 1 calculated according to equation $3.2 \& 3.3$ on methodology part of this paper.

Table 1 the value RCA of the country shows the comparative advantage of the country as well as stated earlier symmetric comparative advantage of the country also shows competitiveness of country. Although if the value of RCA is more than 4 the country under consideration has high comparative advantage and in the same approach if the value SRCA near one shows highly competitive in exporting product coffee in this case. Thus, in this study, Ethiopia has the highest RCA value (more than 4) however the market share of Ethiopia reaches only 2.94 percent, which is much smaller than Brazil, reaching 27.81 percent. The implication is that country's trade pattern having comparative a country may experience not/less competitive due to the fact that, some bilateral trade is small in amount and not fully in- lined with its RCA (Martin \& Tomáš, 2019). Once more, relatively high transaction cost in coffee trading no emphasis placed on quality control helped to improve the country's performance, as mirrored by decreasing of the RCA from 11.02 in 1990 to 6.90 in 1991, with the RSCA decreasing from 0.83 to 0.75 thereby total export also decreases in this period as stated. The transitional government following the short improvement in export performance between 1994 and 1996 related to an increase in RCA from 12.84 to 15.28 and etc.

Table 1: Ethiopian coffee export performance

\begin{tabular}{|c|c|c|c|c|c|c|}
\hline Year & $\begin{array}{r}\text { world } \\
\text { Ration }\end{array}$ & $\begin{array}{l}\text { Ethiopia Agri- } \\
\text { Export }\end{array}$ & $\begin{array}{l}\text { Ethiopia Coffee } \\
\text { Export }\end{array}$ & $\begin{array}{l}\text { Ethiopia } \\
\text { Ratio }\end{array}$ & RCA Index & SRCA \\
\hline 1990 & 0.06 & 323.34 & 205.85 & 0.64 & 11.02 & 0.83 \\
\hline 1991 & 0.07 & 356.32 & 175.85 & 0.49 & 6.90 & 0.75 \\
\hline 1992 & 0.08 & 375.56 & 235.85 & 0.63 & 7.58 & 0.77 \\
\hline 1993 & 0.05 & 353.22 & 215.85 & 0.61 & 11.29 & 0.84 \\
\hline 1994 & 0.06 & 392.43 & 305.85 & 0.78 & 12.84 & 0.86 \\
\hline 1995 & 0.05 & 421.94 & 275.85 & 0.65 & 12.98 & 0.85 \\
\hline 1996 & 0.05 & 481.24 & 342.54 & 0.71 & 15.28 & 0.88 \\
\hline 1997 & 0.05 & 553.98 & 350.80 & 0.63 & 11.64 & 0.84 \\
\hline 1998 & 0.05 & 560.28 & 386.36 & 0.69 & 12.97 & 0.86 \\
\hline 1999 & 0.05 & 448.58 & 271.83 & 0.61 & 12.98 & 0.86 \\
\hline 2000 & 0.03 & 964.59 & 518.01 & 0.54 & 15.40 & 0.88 \\
\hline 2001 & 0.03 & 772.75 & 294.67 & 0.38 & 14.33 & 0.87 \\
\hline 2002 & 0.02 & 834.02 & 332.13 & 0.40 & 16.41 & 0.89 \\
\hline 2003 & 0.02 & $1,024.21$ & 383.50 & 0.37 & 16.57 & 0.89 \\
\hline 2004 & 0.02 & $1,229.70$ & 495.22 & 0.40 & 18.08 & 0.90 \\
\hline 2005 & 0.02 & 926.20 & 349.93 & 0.38 & 16.66 & 0.89 \\
\hline 2006 & 0.02 & $1,934.28$ & 783.82 & 0.41 & 17.15 & 0.89 \\
\hline 2007 & 0.02 & $1,494.38$ & 375.49 & 0.25 & 10.79 & 0.83 \\
\hline 2008 & 0.02 & $1,733.89$ & 447.02 & 0.26 & 11.26 & 0.84 \\
\hline 2009 & 0.02 & $1,618.17$ & 382.90 & 0.24 & 10.12 & 0.82 \\
\hline 2010 & 0.02 & $2,744.50$ & 518.16 & 0.19 & 8.10 & 0.78 \\
\hline 2011 & 0.03 & $3,618.76$ & 689.45 & 0.19 & 7.16 & 0.75 \\
\hline 2012 & 0.02 & $3,969.47$ & 695.12 & 0.18 & 7.38 & 0.76 \\
\hline 2013 & 0.02 & $4,076.94$ & 752.78 & 0.18 & 9.64 & 0.81 \\
\hline 2014 & 0.02 & $4,624.04$ & 876.48 & 0.19 & 8.13 & 0.78 \\
\hline 2015 & 0.03 & $4,047.10$ & 855.52 & 0.21 & 8.23 & 0.78 \\
\hline 2016 & 0.03 & $3,977.01$ & 850.49 & 0.21 & 8.41 & 0.79 \\
\hline 2017 & 0.03 & $2,287.99$ & 807.71 & 0.35 & 12.61 & 0.85 \\
\hline 2018 & 0.03 & $3,097.11$ & 917.00 & 0.30 & 11.82 & 0.84 \\
\hline
\end{tabular}

Source: own computation (2020)

Thus, change in the competitiveness of commodity in a country during a certain period can determine the position of the country in the international market and determine efficient use of its comparative advantage. 
Changes in export during 1990/1991 until 2017/2018 indicated dynamic and shift of competitiveness between world coffee producers.

\subsection{Result of Econometric Analysis}

\subsubsection{Unit Root (Stationarity) tests}

Table 3 presents the outcomes from both the Augmented Dickey Fuller (ADF) and Phillips-Perron (PP) unit root tests conducted on the variables in the model. As shown in Table 3, two out of the seven variables total coffee export (LnTCE) and world total coffee production (LnWpd) were stationary at both $\mathrm{I}(0)$ \& I(1). The remaining five variables were stationary at First difference. The stationary result leaves the study with series under I $(0)$ and I (1) i.e. no variable with I (2) hence,ARDL bounds approach was adopted to test for cointegration among variables in the model.

Table 3: ADF and PP Unit Root Test:levels and first difference

\begin{tabular}{|c|c|c|c|c|c|c|}
\hline \multicolumn{4}{|c|}{ Augmented Dickey-Fuller (ADF) } & \multicolumn{3}{|c|}{ Philip Peron (PP) } \\
\hline Variables & T-Stat & $\begin{array}{l}\text { Critical } \\
\text { Value }\end{array}$ & Trend Specification & T-Stat & $\begin{array}{c}\text { Critical } \\
\text { value }\end{array}$ & Integration \\
\hline \multirow{3}{*}{ LnTCE } & -4.34 & \multirow{3}{*}{$5.98 *$} & \multirow{3}{*}{$\begin{array}{l}\text { intercept with a } \\
\text { linear trend }\end{array}$} & -4.34 & \multirow{3}{*}{$5.98 *$} & \multirow{3}{*}{$\mathrm{I}(0) \& \mathrm{I}(1)$} \\
\hline & -3.59 & & & -3.59 & & \\
\hline & -3.23 & & & -3.23 & & \\
\hline \multirow{3}{*}{$\mathrm{D}(\mathrm{FDI})$} & -3.7 & \multirow{3}{*}{$6.26^{*}$} & \multirow{3}{*}{ Intercept only } & -3.7 & \multirow{3}{*}{$6.45^{*}$} & \multirow{3}{*}{$\mathrm{I}(1)$} \\
\hline & -2.98 & & & -2.98 & & \\
\hline & -2.63 & & & -2.63 & & \\
\hline \multirow{3}{*}{$\mathrm{D}(\mathrm{Cpr})$} & -3.73 & \multirow{3}{*}{$4.14 *$} & \multirow{3}{*}{ Intercept only } & -3.7 & \multirow{3}{*}{$4.29 *$} & \multirow{3}{*}{$\mathrm{I}(1)$} \\
\hline & -2.99 & & & 2.99 & & \\
\hline & -2.63 & & & -2.63 & & \\
\hline \multirow{3}{*}{ D(LnRER) } & -4.37 & \multirow{3}{*}{$-5.59^{*}$} & \multirow{3}{*}{$\begin{array}{l}\text { intercept with a } \\
\text { linear trend }\end{array}$} & -4.34 & \multirow{3}{*}{$-3.61 * *$} & \multirow{3}{*}{$\mathrm{I}(1)$} \\
\hline & -3.6 & & & -3.59 & & \\
\hline & -3.24 & & & -3.23 & & \\
\hline \multirow{3}{*}{$\mathrm{D}(\mathrm{LnWpr})$} & -3.74 & \multirow{3}{*}{$-3.14 * *$} & \multirow{3}{*}{ Intercept only } & -3.7 & \multirow{3}{*}{$-4.49 *$} & \multirow{3}{*}{$\mathrm{I}(1)$} \\
\hline & -2.3 & & & -2.98 & & \\
\hline & -2.63 & & & -2.63 & & \\
\hline \multirow{3}{*}{$\mathrm{D}(\mathrm{LnDpd})$} & -3.7 & \multirow{3}{*}{$-5.91 *$} & \multirow{3}{*}{$\begin{array}{l}\text { intercept with a } \\
\text { linear trend }\end{array}$} & -3.7 & \multirow{3}{*}{$-6.05^{*}$} & \multirow{3}{*}{$\mathrm{I}(1)$} \\
\hline & -2.98 & & & -2.98 & & \\
\hline & -2.63 & & & -2.63 & & \\
\hline \multirow{3}{*}{$\mathrm{D}(\mathrm{RCA})$} & -3.77 & & & -3.7 & & \\
\hline & -3 & $-3.18 * *$ & Intercept only & -2.98 & $-31.15^{*}$ & $\mathrm{I}(1)$ \\
\hline & 2.64 & & & -2.63 & & \\
\hline & -4.32 & & & -4.32 & & \\
\hline LnWpd & -3.58 & $-4.87 *$ & intercept with linear & -3.58 & $-4.67 *$ & $\mathrm{I}(0) \& \mathrm{I}(1)$ \\
\hline & -3.23 & & & -3.23 & & \\
\hline
\end{tabular}

$*, * * 1 \%$ and $5 \%$ level of significance

Source: own computation (2020)

\subsubsection{Lag length selection criteria}

If the lag length is too small then errors would bias the test result and if it is too large, then the power of the test would suffer by losing a degree of freedom. This leads to the fact that there is some optimal lag length (Mohammadnur, 2012).Hence, the study has selected the optimal lag length of to Akaike Information Criterion (AIC). 
Table 4: Lag Length Selection Criteria

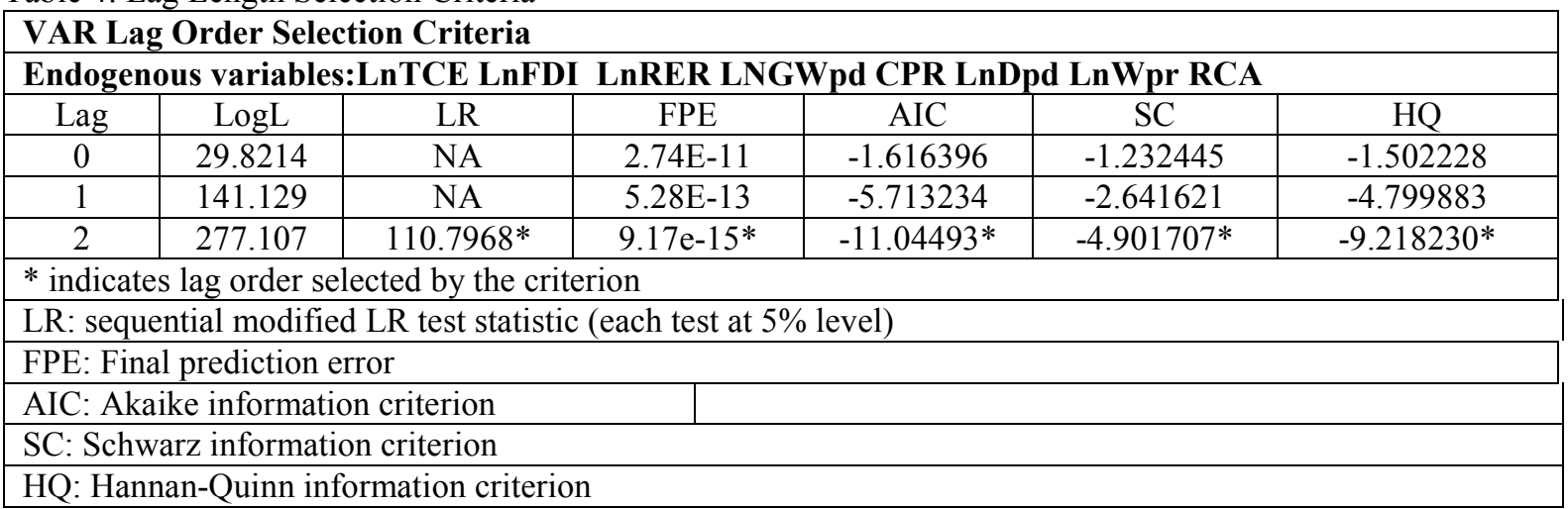

Source: own computation (2020)

5.3.3 Bound testing or Testing for cointegration

Table 5: Results of bounds test using F-statistic of ARDL Model

\begin{tabular}{|l|l|l|}
\hline \multicolumn{2}{|l|}{ ARDL Bounds Test } \\
\hline Null Hypothesis: No long-run relationships exist \\
\hline Test Statistic & Value & K \\
\hline F-statistic & 72.3814 & 7 \\
\hline \multicolumn{2}{|c|}{ Critical Value Bounds } \\
\hline Significance & I $(0)$ Bound & I (1) Bound \\
\hline $10 \%$ & 1.99 & 2.94 \\
\hline $5 \%$ & 2.27 & 3.28 \\
\hline $2.50 \%$ & 2.55 & 3.61 \\
\hline $1 \%$ & 2.88 & 3.99 \\
\hline
\end{tabular}

Source: own computation (2020)

Basing on the bounds test results in Table 5, we reject the null hypothesis of no cointegration among variables since the F-statistic is greater than the upper bound critical values at all levels of significance. We therefore conclude the presence of cointegration since Table 5 shows computed value of F-statistic (72.3814) is greater than the upper bound value of F-statistic at 10\% (2.94), at 5\% (3.28), at 2.5\% (3.61), and 1\% (3.99) level of significance.

5.3.4 ARDL Longrun and short-run result analysis

Table 6: Long-run Result Coefficients Using ARDL Model $(1,2,1,1,1,2,1)$

\begin{tabular}{|c|r|r|r|c|}
\hline \multicolumn{5}{|c|}{ Long Run Coefficients } \\
\hline Variable & Coefficient & Std. Error & t-Statistic & Prob. \\
\hline LnFDI & -0.180165 & 0.083411 & -2.159965 & $0.0561^{* *}$ \\
\hline LnRER & 0.479186 & 0.130625 & 3.668409 & $0.0043^{*}$ \\
\hline LnWpr & -1.578283 & 0.451201 & -3.497962 & $0.0057^{*}$ \\
\hline Cpr & -0.244491 & 0.042529 & -5.748787 & $0.0002^{*}$ \\
\hline LnDpd & 1.263694 & 0.165390 & 7.640716 & $0.0000^{*}$ \\
\hline LnWpr & 0.228899 & 0.061557 & 3.718497 & $0.0040^{*}$ \\
\hline CA & 0.014848 & 0.049029 & 0.302839 & 0.7682 \\
\hline
\end{tabular}

$*, * * 1 \%$ \& $10 \%$ significant level respectively

Source: own computation (2020)

For easier interpretation, as per equation 3.12, we can rewrite the long-run equilibrium relationship as follows: $L n T C E=-0.1802 * \operatorname{LF} F I+0.4792 * \operatorname{LnRER}-1.5783 * \operatorname{LnWpd}-0.2445 * \mathrm{Cpr}+1.2637 * \operatorname{LnDpd}+0.2289 \mathrm{LnWpr}+$ $0.0148 * R C A+40.8555$ 
Table 7: Short-run Result Coefficients Using ARDL Model (1, 2, 1, 1, 1, 2, 1)

\begin{tabular}{|c|c|c|c|c|}
\hline \multicolumn{4}{|c|}{ Dependent Variable: LOGTEXPORT } & \\
\hline \multicolumn{5}{|c|}{ Selected Model: ARDL $(1,2,1,1,1,2,1)$} \\
\hline \multicolumn{5}{|c|}{ Co-integrating Form } \\
\hline Variable & Coefficient & Std. Error & t-Statistic & Prob. \\
\hline $\mathrm{D}(\mathrm{LnFDI})$ & 0.111038 & 0.317080 & 0.350189 & 0.7335 \\
\hline $\mathrm{D}(\mathrm{LnFDI}(-1))$ & -0.957594 & 0.284877 & -3.361432 & $0.0072 *$ \\
\hline D(LnRER) & 3.210652 & 0.367583 & 8.734503 & $0.0000 *$ \\
\hline $\mathrm{D}(\mathrm{LnWpd})$ & -0.603873 & 0.369801 & -1.632969 & 0.1335 \\
\hline $\mathrm{D}(\mathrm{Cpr})$ & -0.089111 & 0.047877 & -1.861270 & $0.0923 * *$ \\
\hline $\mathrm{D}(\mathrm{LnDpd})$ & 1.808413 & 0.180377 & 10.025730 & $0.0000^{*}$ \\
\hline $\mathrm{D}(\operatorname{LnDpd}(-1))$ & 0.377877 & 0.202654 & 1.864642 & $0.0918 * *$ \\
\hline $\mathrm{D}(\mathrm{LnWpr})$ & 0.107827 & 0.097764 & 1.102937 & 0.2959 \\
\hline $\mathrm{D}(\mathrm{RCA})$ & 0.019955 & 0.066266 & 0.301127 & 0.7695 \\
\hline ECM $(-1)$ & -1.343919 & 0.100170 & -13.41643 & 0.0000 \\
\hline R-squared & 0.9905 & Akaike info criteric & & -2.013478 \\
\hline Adjusted R-squared & 0.97 & Schwarz criterion & & -1.197581 \\
\hline Prob(F-statistic) & 0.000000 & Hannan-Quinn crit & & -1.770869 \\
\hline $\mathrm{DW}$ & 2.069698 & F-statistic & & 65.36973 \\
\hline
\end{tabular}

*, ** 1\% \& 10\% significant level respectively

Source: own computation (2020)

Goodness of fit $\left(\mathbf{R}^{2}\right)$ :The model was found to be a good fit for the data. This conclusion is based on the high Rsquared of 0.99 . This suggests that $99 \%$ of the alterations in the explained variable (TCE) are accounted for by the independent variables in the model and only $1 \%$ of variation explained by an exogenous variable not explained in the model

F-statistic and the overall performance of the model:The joint statistical performance of the model shown by the F-statistic is 65.36 with a probability value of prob(F-statistics 0.0000 ) which suggests that in the long run, the explanatory variables jointly determine TCE in Ethiopia.

\subsection{Model Diagnostic Tests}

Table 8: Results of diagnostic tests carried out.

\begin{tabular}{|l|l|c|c|c|l|}
\hline Test statistics & \multicolumn{1}{|c|}{$\begin{array}{c}\text { Test carried } \\
\text { out }\end{array}$} & Null hypothesis & F-statistcs & $\begin{array}{c}\text { p- } \\
\text { value }\end{array}$ & Conclusion \\
\hline Normality & Jarque-Bera test & $\begin{array}{c}\text { Residuals normally } \\
\text { distributed }\end{array}$ & 0.02945 & 0.98 & $\begin{array}{l}\text { Fail to reject Null } \\
\text { hypothesis }\end{array}$ \\
\hline Serial correlation & $\begin{array}{l}\text { BG Serial LM } \\
\text { test }\end{array}$ & No serial correlation & 0.43773 & 0.658 & $\begin{array}{l}\text { Fail to reject Null } \\
\text { hypothesis }\end{array}$ \\
\hline Heteroscedasticity & $\begin{array}{l}\text { Breusch-Pagan- } \\
\text { Godfrey }\end{array}$ & Homoscedasticity & 0.54524 & 0.245 & $\begin{array}{l}\text { Fail to reject Null } \\
\text { hypothesis }\end{array}$ \\
\hline Ramsey RESET & $\begin{array}{l}\text { Ramsey RESET } \\
\text { Test }\end{array}$ & no omitted variables & 0.009746 & 0.923 & $\begin{array}{l}\text { Fail to reject Null } \\
\text { hypothesis }\end{array}$ \\
\hline $\begin{array}{l}\text { Redundant } \\
\text { Variables }\end{array}$ & $\begin{array}{l}\text { Likelihood ratio } \\
\text { test }\end{array}$ & $\begin{array}{c}\text { Coefficient of Lagged } \\
\text { values jointly significant }\end{array}$ & 19.936 & 0.000 & $\begin{array}{l}\text { Fail to reject Null } \\
\text { hypothesis }\end{array}$ \\
\hline Wald statistics test & $\begin{array}{l}\text { Coefficient } \\
\text { Statistics Test }\end{array}$ & $\begin{array}{c}\text { Coefficient of Lagged } \\
\text { values are zero }\end{array}$ & 16.8466 & 0.000 & $\begin{array}{l}\text { Fail to reject Null } \\
\text { hypothesis }\end{array}$ \\
\hline
\end{tabular}

Source: Own Computation (2020)

\subsection{Discussions of Major Findings}

The outcomes from the model estimation show that in the long run, all variables have statistically significant impacts on TCE. LnFDI has a negative and statistically significant (at 10\% level of significance) impact on on TCE. In other words ceteris peribus, a unit increase in foreign direct investment (FDI) successively; decreases TCE by 0.18 percent. However, the direction of this variable, in the long run, is not expected in this manner. This result is resembled with Boansi et.al (2014) confirms the inverse relationship between agricultural exports performance of FDI in Ghana. There are contradicting results in literature with respect to inflows FDI role in explaining the growth of recipient countries. For many countries, according to UNCTAD (2018) report, FDI is an important component in determining the supply side of the export. Thus, generally, this study agree with empirical analysis Boansi D. (2014) shows and summarize that foreign direct investment (FDI) impact depends on its motive, 
whereby export oriented FDI will promote the export performance of the exported commodities.

Real exchange rate has a statistically significant (at 5\% level of significance) positive impact on TCE in the long run. Keeping other factors constant, a unit changes in real exchange rate results 0.48 percent change in the amount of total coffee export in the same direction. The direction of this variable is maintained as expected and is quite logical that due to the nature of the product they produce exports of LDCs are price inelastic in the international market. In theory, Marshal-learner condition, real exchange rate movements related to the growth of export performance in the long run. In literature, this result once more agreed with autonomous effort of (Samuel,2012:Abate,2013:Sawore,2015:NBE, 2017:Ahmed et.al, 2018:UNCTAD,2018).However, some studies such as (Alelign,2014:Hassen,2015:Abolagba et.al,2016:Monineath,2018) shows how real exchange rate has negative significant effect on export performance. Thus, positive and significant coefficient also shows that export may influenced by exchange rate policy

The sign of the global price of coffee expected to be positive and hopefully maintained implying higher world coffee price makes export more profitable and attractive. The direction of this variable, in the long run, is resembled with the effort of Samuel (2012) \& Gebretsadik (2018) but against Netsanet (2016). Thus, in the long run, since Price movements reflect the changing demand and supply conditions a unit increase in world price leads to 0.22 percent in a substantial increase in total coffee export which is highly responsive at a $1 \%$ significant level. Generally,this finding agreed with theory of international trade and AfDB (2017) with 'small country with open economy assumption', world prices and market conditions as exogenously given Ethiopia as a small country with an open economy has no power to influence the price it receives or the price getting for its coffee and not significantly correlated with the volume of its export.

Furthermore, a unit increase in the world coffee price ratio would decrease the total amount of coffee exported by 0.24 percent, which is substantially at $1 \%$ significant level against Boansi (2013). The effect of this variable was a priori believed could go either way. The implication for this at time of increasing world price reflects domestic factors, such as continuous competitiveness of the domestic market (domestic consumption), lower transmission of price increment the extensive nature (many intermediaries) of the supply chain inefficiency for coffee in Ethiopia and the strong effect of transaction cost and fear of long-run fall in coffee prices which brings production risk of producers. Even under normal circumstances, David \& Christian (2013) showed that when there is an expectation in increase in this ratio farmers are mostly victimized in production.

A unit increase in domestic coffee production increases total coffee export by 1.2 percent in the long run significant at a $1 \%$ level which is highly responsive. Thus, in this finding the positive economic benefits of coffee production since coffee can be a driver of development in Ethiopia's economic growth and poverty reduction through foreign exchange earnings. The variable world supply of coffee is negatively and significantly affects the dependent variable a prior expectation for this variable also maintained in the long run at a $1 \%$ significant level. Thus, a unit increase in the world production of coffee and supplied to global market thereby subsequently decrease total export of Ethiopia by 1.57 percent in the long run consistence with the effort of Tadesse (2015) and Zekarias \& Degye (2019).

Generally, the intercept $(\mathrm{C})$ term in long run also found highly significant and positive, implying that conditions in all the other variables remain constant, and Ethiopia would continue to export a significant amount of total green coffee over time to the world market. This reflects a highly competitive nature of the world coffee export industry and a relatively brings high power of Ethiopia in terms of share in the world market. Therefore, there is long-run causality that follows from independent variables to the dependent variable in at least one direction accordingly.

In the short run,the negative relationship between lagged FDI D(FDI (-1)) and total coffee export in the short run shows a one percent increase in FDI would decrease total amount of coffee export by 0.96 percent in Ethiopia. This result agreed with Hassen (2015) but against Boansi et.al (2014) that shows and summarizes that foreign direct investment (FDI) impact depends on its motive, whereby export-oriented FDI would promote the export performance of the exported commodities. Thus, in this study, it is lagged FDI has a significant negative effect on overcoming total coffee export supply due to the fact capital inflow from foreign aid invested is dependent on motive and time adjustment in the short run.

In Ethiopia the real exchange is demarcated as foreign currency in terms of ETB such that a rise exchange rate can be interpreted as depreciation. Thus, a one percent increase (depreciation) in exchange rate in the shortrun increase total amount of coffee export by 3.2 percent in Ethiopia.However, in both, short run and long run period in the macroeconomic point of view continuous devaluation without other macroeconomic variables adjustment may no significant effect in improving either export or competitiveness of the country in the international market because it may be affected by inflation and increase production cost (input price) in a coffee export transaction

Domestic coffee production is the other variable that provides a base to develop a strong total coffee export supply from Ethiopia to different destinations. Thus, a unit increases in current total domestic production increases total coffee export by 1.8 percent significant at $1 \%$ level in Ethiopia annually. The direction of this variable in the 
short run as well as in the long run showed a positive sign with the total coffee exports as expected and hypothesized.The positive sign for domestic coffee production implies that an increase in production would lead to an increase in total amount of coffee export brings larger incentive to exporters.Furthermore, a one percent increases in lagged (reserved) domestic production increase 0.38 percent increase in total amount of coffee export in Ethiopia annually at a $10 \%$ significance level but the responsiveness of lagged domestic production quite low as compared to current domestic production. This is for the reason that, according to the ECTA-365/2015 proclamation, old coffee crops either domestically consumed or exported until the next coffee crop year.

World supply/production of coffee has a negative coefficient with insignificant effect due to the fact that, according to simple microeconomic theory coffee is homogenous product hence, consumers are actually exhibiting different preferences (heterogeneous) for goods that originate from different regions, and thus consumers exhibit constant elasticity assumption regardless of country of origin, world coffee produced with a different season and,Ethiopia have low global share coffee production and export which is with against Tadesse (2015) in the short run.

An inverse relationship between total coffee export and explanatory variable the price ratio/relative price also observed. This means a one percent decrease in price ration would increases the amount of total coffee export by 0.08 percent in the short-run and significant at 10\% level which similar with Sawore (2015). Thus, negative response price ration reflects a high dependence of farmers on the crop for sustenance but mistreated. In addition to this, any negative response with price ratio means that Ethiopia not only a major producer and exporter of coffee, but also a major consumer in Africa David and Christian (2013), and thus, high domestic demand brings a decrease in price ratio. Decisions of exporters also depend not only on such ratios but also on other vital local and international factors.

The coefficient of world coffee price was positive but insignificant in the short run which is unexpected but similar to Samuel (2012) who stated and confirmed world price had only a long-run effect against with Teshome (2009). When foreign price level increases, domestic exporters would get the incentive and willingness to supply and ship their sold future contracts in the short run, however in this circumstance exporters could not have an immediate response from their foreign customers to receive future coffee contracts shipment since coffee market is buyers' market due to the concept of primary commodity market imperfection (AfDB, 2017). The inference of this view was the amount of total coffee export in Ethiopia has driven more by volume faced by exporters than by actual price exported which sustains competitiveness in quantity driven export rather than price-driven exports. Besides, export demand theory believed that increase quantity demanded with a drop in price and vice versa in short run. Furthermore, Ethiopian coffee exporters are price takers in the world coffee market and unable to pass extra cost against foreign buyers, an increase in domestic cost would crowd out their profit and reduce the incentive to export, and thereby export volume would decline. Exporters in the short run may also face shortage and unable to satisfy their foreign customers by availing on-time shipment immediately when world price increases. Thus, it calls for competitive advantage of Ethiopia in export of this commodity is improving on the quality of the country's exports by value addition and attracting higher prices could, therefore, go a long way to increase value of total coffee exports from Ethiopia.

The level of comparative advantage (as an index of competitiveness Revealed Comparative advantage or export performance index) observed and coefficient was positive but not significant in the export of coffee. This ensures numerous implications. Hence Kowalski, P. (2011) comparative advantage remains an important determinant of trade, however, differences in policy settings and policy performance that create relative differences in productivity and give rise to trade gains as well as Mohammed (2017) showed that, type of state or government intervention could bring distortion in comparative advantage. An improvement in the country's competitiveness or productivity as in Krugman $(1990,1994)$ as well reflects addressing inefficiencies in the subsector and justification of influences that could have conveyed an insignificant impact here. Thus, this study higly belive that continuous growth in production of coffee and thereby bringing a significant amount of green coffee export of Ethiopia still could not use its comparative advantage to produce \& export this product most efficiently. Trade theory; also suggests that international trade development significantly influenced by market imperfections (domestic \& foreign) and heterogeneity of consumer preferences brings the variable insignificant. From the positive sign of this coefficient, we can also bear in mind that an indication of $\mathrm{H}-\mathrm{O}$ effect (differences in factor endowments) dominates the Linder effect in case of Ethiopia's coffee export flows. Furthermore, coffee exporters are facing the same or similar difficulties and most of the problems occurring within the exporters' is from the internal environment, problems occurring within the economic branch (export sector) and export markets, problems occurring within the policy (like minimum price-setting) pursued by the government.

In the model, short-run dynamics are captured by an error correction model (ECM (-1)). Thus, the ECM (Error Correction Model) explained the adjustment process and speed to any short-run shock towards long-run equilibrium (equation 3.13). Thus, in this study speed of adjustment measures the speed at which Ethiopian total coffee export returns to equilibrium after changes in defined previous year export. Since, then the error correction term has a coefficient of -1.3439 , which was highly significant. The value of error correction term suggested that 
134.4 percent of any disequilibrium in the short run would adjust each year (Table 7). Therefore, this means that any short-run adjustment fully compensated within almost 1.34 year time to return to its long run for total coffee export supply which is highly responsive.

\subsection{Granger Causality Test}

I measures the ability to predict the future values of a time series based on the previous values of another time series. To capture the direction of causality between total coffee export and major determinants in Ethiopia the Pair-wise Granger-causality approach adopted after existence of co-integration among variables that could determine and build at least one long-run causal effect running to either direction.

Table 9: Pairwise Granger Causality Tests

\begin{tabular}{|c|c|c|c|c|}
\hline Pairwise Granger Causality Tests & & & & Direction of \\
\hline Null Hypothesis: & Obs & F-Statistic & Prob. & causality \\
\hline LnFDI does not Granger Cause LnTCE & \multirow[t]{2}{*}{27} & 5.11646 & 0.015 & \multirow{6}{*}{ undirectional } \\
\hline LnTCE does not Granger Cause LnFDI & & 0.90633 & 0.4186 & \\
\hline LnWpd does not Granger Cause LnTCE & \multirow[t]{2}{*}{27} & 3.89213 & 0.0357 & \\
\hline LnTCE does not Granger Cause LnWpd & & 1.54700 & 0.2352 & \\
\hline Cpr does not Granger Cause LnTCE & \multirow[t]{2}{*}{27} & 3.17029 & 0.0617 & \\
\hline LnTCE does not Granger Cause Cpr & & 6.03532 & 0.0081 & \\
\hline LnRER does not Granger Cause LnTCE & \multirow[t]{2}{*}{27} & 9.23830 & 0.0012 & \multirow[t]{4}{*}{ bidirectional } \\
\hline LnTCE does not Granger Cause LnRER & & 12.1369 & 0.0003 & \\
\hline LnDpd does not Granger Cause LnTCE & \multirow[t]{2}{*}{27} & 1.57905 & 0.0287 & \\
\hline LnTCE does not Granger Cause LnDpd & & 4.31670 & 0.0262 & \\
\hline LnWpr does not Granger Cause LnTCE & \multirow[t]{2}{*}{27} & 0.04623 & 0.9549 & \multirow[t]{4}{*}{ independent } \\
\hline LnTCE does not Granger Cause LnWpr & & 3.11261 & 0.0645 & \\
\hline RCA does not Granger Cause LnTCE & \multirow[t]{2}{*}{27} & 0.31756 & 0.7312 & \\
\hline LnTCE does not Granger Cause RCA & & 2.50702 & 0.1045 & \\
\hline
\end{tabular}

Source: own computation (2020)

The technique used to determine the direction of causality between variables in the long run expending the F-statistic: the decision rule is that the null hypothesis of no Granger causality rejected if the probability value is greater than 5\% standard significance level. It could observed that, out of seven independent variables only two variables world price ( $\mathrm{LnWpr}$ ) and index of competitiveness (RCA) as dummy variable independent to grangercause total coffee export. This implies comparative advantage in Ethiopia could not cause total coffee export since a country failed to improve capacity to use its comparative advantage properly as shown in Kowalski (2011) in which comparative advantage focuses strongly on the interaction of policies and regulatory frameworks with specific needs of particular sectors of the economy. World price is also independent to Granger-cause total coffee export of Ethiopia which is against to Stockman (2010). This implies Ethiopia as a small country with an open economy there is no enough evidence to conclude that increase in Ethiopian total coffee export causes the decline in world coffee prices as well as no other coffee producing nations should not blame Ethiopia for the continuous decrease in world prices.

In other words, the test result shows that there exists a unidirectional causality from LnWpd and LnFDI to TCE. Furthermore, the result of LnRER \& LnDpd has bi-directional causality among independent variables on total coffee export, which is parallel to Tadese (2015) and Hassen (2015) respectively.Thus, in this case generally, the result of the Granger causality is as expected and reasonable. Since then kindly, intercept (C), term on Table 8 also found highly significant and positive, validating that conditions in all the other variables remain constant to build long-run causality follow from the independent variables to dependent variables in the long run.

\subsection{Analysis Impulse Response of Total Coffee Export}

Impulse response function, a shock that one variable can affect itself and be transmitted into all other endogenous variables in the model. As can be seen from Table (11), the IRF of total coffee export responds positively to a shock in the real exchange rate over the whole period and the magnitude of the response is zero at the initial period and there was a positive response of TCE to the real exchange rate of the domestic currency, which is permissible. 
Table 10: Impulse Response of Total Coffee Export

\begin{tabular}{|c|c|c|c|c|c|c|c|c|}
\hline Response of TEXPORT \\
\hline Period & LnTCE & LnFDI & LnRER & LnWpd & Cpr & LnDpd & LnWpr & RCA \\
\hline $\mathbf{1}$ & 0.2852 & 0.0000 & 0.0000 & 0.0000 & 0.0000 & 0.0000 & 0.0000 & 0.0000 \\
\hline $\mathbf{2}$ & 0.0602 & -0.0414 & 0.0088 & -0.0454 & -0.0265 & 0.0076 & 0.0352 & -0.0248 \\
\hline $\mathbf{3}$ & 0.1608 & 0.0398 & 0.0237 & 0.0282 & -0.086 & -0.008 & 0.0416 & -0.0192 \\
\hline $\mathbf{4}$ & 0.1197 & -0.0055 & 0.0064 & -0.0243 & -0.0842 & -0.0027 & 0.0605 & 0.0013 \\
\hline $\mathbf{5}$ & 0.1456 & -0.0246 & 0.0274 & 0.0165 & -0.0371 & -0.0083 & 0.0512 & -0.0193 \\
\hline $\mathbf{6}$ & 0.1337 & 0.0007 & 0.0183 & -0.011 & -0.0614 & 0.0035 & 0.0364 & -0.0065 \\
\hline $\mathbf{7}$ & 0.1342 & -0.006 & 0.0356 & 0.0030 & -0.0598 & -0.0085 & 0.0454 & -0.0156 \\
\hline $\mathbf{8}$ & 0.1329 & -0.006 & 0.0157 & -0.0046 & -0.0636 & 0.0008 & 0.0394 & -0.0072 \\
\hline $\mathbf{9}$ & 0.1390 & -0.013 & 0.0320 & 0.0017 & -0.0532 & -0.0053 & 0.0439 & -0.0125 \\
\hline $\mathbf{1 0}$ & 0.1316 & -0.009 & 0.0223 & -0.0043 & -0.0569 & 0 & 0.0377 & -0.0108 \\
\hline
\end{tabular}

Source: own computation (2020)

Since the depreciation of the domestic currency, ETB generally leads to exported commodity (coffee in this case) more cheaply to international market, which in turn imposes pressure on the TCE. The TCE has also responded positively to a shock in world coffee prices and response of TCE to world coffee price is realistic. This is because in simple microeconomic theory increase in world coffee price tips to an increase in the willingness of exporters to supply for coffee commodity, the ability of exporter to ship their defaulted contract to international market and increase in incentive of government to exporters and hence would lead to an increase in the TCE.

Generally,it is also shown that in the first period a one standard deviation disturbance originating from the other variables do not have any impact on TCE responds positively to its shocks for the first year which is consistence with Bihonegn and Kurabachew (2018). Conversely, Muhammad et.al (2018) while investigating of coffee export dynamics in Indonesia showed that, each variable produce a sharp shock at the beginning of the period but would reach a stable at the end of the period. Thus, from this finding one can bear in mind that, a single time shock in one variable may leave permanent shock on another variable.

\subsection{Analysis of variance decomposition of total coffee export}

Variance decomposition provides information about the relative importance of each random innovation in affecting the variables based on the Cholesky factor can change dramatically which alter the ordering of the variables in the VEC. This section analyzed how the variant of a variable is determined by the role of other variables as well as the role of the variable itself and could see the magnitude of the difference between variants before and after a given shock, either shock from self or shock from other variables.

Table 11: Decomposition of Forecast Error Variance of Total Coffee Export

\begin{tabular}{|l|l|l|l|l|l|l|l|l|l|}
\hline Variance Decomposition of TCE \\
\hline Period & S.E. & LnTCE & LnFDI & LnRER & LnWpd & Cpr & LnDpd & LnWpr & RCA \\
\hline $\mathbf{1}$ & 0.2852 & 100.00 & 0.0000 & 0.0000 & 0.0000 & 0.0000 & 0.0000 & 0.0000 & 0.0000 \\
\hline $\mathbf{2}$ & 0.3022 & 93.06 & 1.8067 & 0.0852 & 2.2480 & 0.7479 & 0.0648 & 1.3587 & 0.6243 \\
\hline $\mathbf{3}$ & 0.3600 & 85.52 & 2.4964 & 0.4941 & 2.2015 & 6.1837 & 0.0939 & 2.2978 & 0.7051 \\
\hline $\mathbf{4}$ & 0.3941 & 80.57 & 2.0973 & 0.4392 & 2.1932 & 9.7490 & 0.080 & 4.2732 & 0.5894 \\
\hline $\mathbf{5}$ & 0.4273 & 80.18 & 2.0908 & 0.7869 & 2.0155 & 9.0509 & 0.1048 & 5.0753 & 0.6946 \\
\hline $\mathbf{6}$ & 0.4539 & 79.74 & 1.8531 & 0.8607 & 1.8496 & 9.8162 & 0.0990 & 5.1412 & 0.6344 \\
\hline $\mathbf{7}$ & 0.4808 & 78.86 & 1.665 & 1.3161 & 1.6525 & 10.244 & 0.1151 & 5.4757 & 0.6620 \\
\hline $\mathbf{8}$ & 0.5046 & 78.52 & 1.5257 & 1.3923 & 1.5070 & 10.846 & 0.1048 & 5.5799 & 0.6179 \\
\hline $\mathbf{9}$ & 0.5292 & 78.29 & 1.4439 & 1.5413 & 1.3711 & 10.869 & 0.1057 & 5.7616 & 0.6098 \\
\hline $\mathbf{1 0}$ & 0.5502 & 78.16 & 1.3617 & 1.5911 & 1.2743 & 11.110 & 0.0978 & 5.8009 & 0.5956 \\
\hline $\mathbf{C}$ & & & &
\end{tabular}

Cholesky Ordering: LnTCE LnFDI LnRER LnWpd Cpr LnDpd LnWpr RCA

Source: own computation (2020)

Hence, the variance decomposition of TCE indicates that, in the initial period, the TCE explains $100 \%$ of its variation while the others' contribution is zero (Table 12). However, during the second period (year), $93.0 \%$ of the variation explained by its innovations. The contribution of FDI and the world coffee production, in the $2^{\text {nd }}$ year, comes to about $1.8 \%$ and $2.2 \%$ and other variables jointly contributes only $3 \%$ respectively to bring variations in TCE.

In the long run of the 10 years, $78.16 \%$ portion of the total coffee error variance is explained by its innovation, whereas price ratio and world coffee price contributes to $11.1 \%$ and $5.8 \%$ respectively besides $4.94 \%$ portion of total coffee export in forecasting error variance with other variables in the model. Therefore, in long run variance decomposition of TCE fundamentally explained by its variation; however, the effects of price ratio, world coffee price, and real exchange rate on TCE increase over time wich is consistence with the findings of Muhammad et.al 
(2018) where variance decomposition of Indonesia's coffee export volume, affects the variable itself and there is a significant contribution given by international coffee price and the exchange rate variables. This underlines the effect these three variables over TCE variation and the impact of between them is larger in the long run. Bihonegn and Kurabachew (2018) also estimates and indicate that a greater proportion of the variation in total value of export of Ethiopia is due to its own innovations wich is higly agreed with findings.

\section{CONCLUSIONS AND RECOMMENDATIONS}

The study was attempted to investigate the competitiveness \& its implication and to identify major determinants of coffee export in Ethiopia. On the way to achieve objective of the study, time series with secondary data obtained from NBE, ICO, and UN-COMTRADE Data Base \& UN-FAOSTAT with an Autoregressive Distributed Lag (ARDL) model (bound testing approach to co-integration) could be employed. This could undertake through analyzing competitiveness in exports of coffee, measured by the stability of the Balassa index RCA and RSCA for competitiveness analysis according to trade theory. The result shows that, even though Ethiopia has a comparative advantage in the export of coffee but the global share of coffee export is very small in volume and the value is not inlined with RCA and RSCA to compete in coffee industry.To make Auto-Regressive Distributed Lag (ARDL) bound testing to Co-integration reliable and validated the model undertake different diagnostics tests. The empirical results based on the bound testing approach showed there co-integrating relationship among variables.

The result of long-run estimates clarify that, all variables have statistically significant impacts on TCE.Thus, finding highly reveal that, Foreign Direct Investement, world supply of coffee,price ratio have a negative and statistically significant effect on TCE and real exchange rate, domestic coffee production and world coffee price consistently showed that, positive and statistically significant consequence on total coffee export. Likewise, finding categorises short run results of Ethiopian total coffee export was defined as positive significant function of domestic coffee production and real exchange rate with positive but insignificant effect of Level of RCA and world price as well as negative significant effect of one year lagged function of FDI, price ration and world production of coffee.

The speed of adjustment from the previous year's disequilibrium in total coffee export to the current year's equilibrium is fast in each period, which is 134.4 percent adjustment toward equilibrium each year. Granger causality test confirms and portrayed that unidirectional, bi-directional and independent causality exists between total coffee export with identified variables. Impulse Response Function shows that the shock produced by each variables has no impact at the beginning of the period but then later on devaluation in real exchange rate and an increase in world coffee price increase each year in long run and Forecast Error of Variance Decomposition of total coffee export analysis shows that the shock that affect total coffee export still dominated by its innovation.

The study suggested policy implications emerging from the findings to the coffee export sector. To respond assertively to exogenous variables of world supply and world price domestic by using comparative advantage coffee production should provide a base for the development of the coffee export supply of the country and hence to take along quality driven export rather quantity driven export to attracting higher prices.

To control and determine ultimate degree of vulnerability of commodity price and quality shocks country should largely reduce intervention that could bring distortion in comparative advantage and follow proper institution and flexible policy framework within proper implementation. To avoid the evil effect of production cost which decrease domestic output country needs proper exchange rate policy and should enhance the efficiennt and effective implementation of investment allowances of FDI to bring a strong contribution to the transformation of the composition coffee export.

\section{References}

Abel, Kebede. (n.d). Analysis of Competitiveness and Comparative Advantage in Honey and Bees wax Production. The case of Meskan and Mareko woreda, SNNPR, Ethiopia.

Adeniyi, et.al, (2014).Determinants of Non-oil Export and Economic Growth in Nigeria: An Application of the Bound Test Approach" Journal for the Advancement of Developing Economies. 4. https://digitalcommons.unl.edu/jade/4

Ahmed,et.al.(2018).Export Performance ofHorticultural Sub Sector in Ethiopia: available at www.mdpi.com/journal/horticuture.

Alemayehu, Asfaw Amamo (2014) Coffee Production and Marketing in Ethiopia. Jimma University College of Agriculture and Veterinary Medicine. European Journal of Business. www.iiste.org ISSN 2222-2839 (Online) Vol.6, No.37, 109

Arpine, Sargsyan. (2018). Export Competitiveness: Assessment through the Balassa index (the case of Armenia) Armenian State University of Economics, Gyumri branch, Gyumri, Armenia, 3119

Balassa, (1965).Comparative Advantage Indices Measure Revealed Comparative Advantage from International Comparisons of exports data, and are blind to possible sources of advantage.

Belayneh, Kassa Anagaw, and Wondaferahu, Mullugeta Demissie. (2012). Determinants of Export Performance 
in Ethiopia: Journal of Research in Commerce \& Management: www.abhinavjournal.com ISSN 22771166

Bihonegn, Fenta and Kurabachew, Menber, (2018). Effect of Currency Devaluation on Ethiopia's Major Export Commodities: The Case of Coffee, Oil Seeds, Hides, and Skins. Journal of Economics and Sustainable Development www.iiste.org ISSN 2222-1700 (Paper) ISSN 2222-2855 Vol.9, No.23

Birol, Erkan \& Kazım, Sarıçoban. (2014).Comparative Analysis of the Competitiveness in the Export of ScienceBased Goods Regarding Turkey and EU+13 Countries. International Journal of Business and Social Science Vol. 5, No. 8(1). Turkey

Boansi, D. (2013).Competitiveness and determinants of cocoa exports from Ghana. Int. J. Agric Policy Res. $1(9): 236-254$.

Boansi, et.al. (2014). Investigating the Determinants of Ghana's Agricultural Export Performance: Focus on Banana, Coffee, and Rubber. International Journal of Development Research, 4(7), 1354-1361

CSA (Central Statistical Authority), (2003/04-2017/18). Area and production forecast of major crops: Agricultural sample enumeration surveys, various issues, Addis Ababa, Ethiopia.

David, BOANSI, and Christian, CRENTSIL. (2013). Competitiveness and Determinants of Coffee Exports, Producer Price, and Production for Ethiopia.Journal of Advanced Research in Economics and International Business (JAREIB) V. I, I 1

Dickey, D.A, and Fuller W.(1981).Distributions of the estimators for autoregressive time series with a unit root, Journal of American Statistical Association. pp.427 - 431

Foreoign Agricultural Service, (2018). Ethiopian Coffee annual: Assessments of Commodity and Trade Issues. Global Agricultural Information Network. GAIN Report Number: ET1820, Addis Ababa.

FAO, (2019). National gender profile of agriculture and rural livelihoods - Ethiopia. Country Gender Assessment Series, Addis Ababa. 84 pp. License: CC BY-NC-SA 3.0 IGO

Felix, Chari et.al. (2013). Comparative Advantage of Ethiopia and the Role of International Purchasing Greener Journal of Economics and Accountancy Vol. 2(2), pp. 051-057

Gebretsadik, Gebru. (2018),"Forecasting Analysis of Coffee Export by multivariate Time series Models of Vector Autoregressive and Co-integration: A case study of Ethiopia "International Journal of Computational Engineering Research (IJCER), vol. 08, no. 11. Pp 01-11

Goldstein, M. \& Khan, M., S. (1985). Income and Price Effects in Foreign Trade: in Handbook of International Economics (2nd Ed). Amsterdam: Elsevier Science Publishers.

Gönül, Muratoğlu \& Yusuf Muratoğlu. (2016). Determinants of Export Competitiveness: Evidence from OECD Manufacturing: Journal of Economics and Political Economy. Volume 3 Issue 1 www.kspjournals.org.

Granger, C.W.J., (1983). Co-Investigated Variables and Error-Correction Models, Working Paper, 83-13. University of California, San Diego.

Gujarati, (2004), Basic Econometrics, 4th edition, The MacGraw- Hill Companies.

Hailu, K. (2012). Determinates of Export Growth Rate in Ethiopia: Co-integration and Error Correction Model Analysis. Unpublished Master's Thesis, Addis Ababa University.

Hassen, Beshir Hussien. (2015). Determinants of Coffee Export Supply in Ethiopia: Wollo University P.O. Box 1145, Ethiopia Journal of Economics and Sustainable Development Vol.6, No.5

Idowu Raheem. (2016) Analysis of the effects of oil and non-Oil export on economic Growth In Nigeria. Hal$01401103 \mathrm{v} 2$

International Coffee Organization, (ICO). (2017). ICO annual report, 2017. Available at http://www. ico.org.

International Coffee Organization, (2019). Coffee Development Report (2019a). Growing for Prosperity Economic viability as the catalyst for a sustainable coffee sector.

ITC, (2016).International Trade Centre http//:www.intracen.org

Jambor, A., Toth, A.T. and Koroshegyi, D. (2017) "The Export Competitiveness of Global Cocoa Traders; , online Papers in Economics and Informatics, Vol. 9, No. 3, pp. 27 - 37. ISSN 1804-1930. DOI 10.7160/aol.2017.090303

Latruffe, L. (2010). Competitiveness, Productivity, and Efficiency in the Agricultural and Agri-Food Sectors. OECD Food, Agriculture and Fisheries Papers, No. 30, OECD http://dx.doi.org/10.1787/5km91nkdt6d6-en

Laursen, K. (1998). Revealed Comparative Advantage and the Alternatives as Measures of International Specialization, DRUID Working Paper No. 98-30, Copenhagen, IVS, Copenhagen Business School.

Martin, G. \& Tomáš, D. (2019). Bilateral Trade Flows and Comparative Advantage: Does the Size Matter. Society and Economy doi: 10.1556/204.2019.013

M. H. Pesaran, Y. Shin, and R. J. Smith, (2001). "Bounds testing approaches to the analysis of level relationships," Journal of Applied Econometrics, vol. 16.

Misu, Kim (2019). Export Competitiveness of India's Textiles and Clothing Sector in the United States. Institute of Indian Studies, Hankuk University of Foreign Studies, Seoul: HTTP:// www.mdpi.com/journal/economies

Monineath, (2018).Analysis of Factors Affecting the Export Performance in Cambodia: 
ARDLApproach:JournalofManagement,Economics, and Industrial Organization, Vol.2 No.2, http://doi.org/10.31039/jomeino.2018.2.2.3

Muhammad, Saqib. (2017). Determinants of Exports Competitiveness: An Empirical Analysis through Revealed Comparative Advantage of External Sector of Pakistan.Asian Economic and Financial Review.Vol.6,No.3,DOI: 10.18488/journal.aefr.2017.76.623.633

Muhammad, et.al, (2018). Investigation of Coffee Export Dynamics in Indonesia Volume 11, 1, ISSN $1979-7192$ (Print)https://journal.unesa.ac.id/index.php/bisma/index

Mulat, Alubel Abtew, (2015) Revealed Comparative Advantage of Ethiopian Leather Industry with Selected African Economies. International Journal of Business and Economics Research.Vol.4, No.5, 2015, .doi: 10.11648/j.ijber.20150405.11

Netsant, Ayalew, (2016). Determinants of Agricultural Export Performance in Ethiopia ST. Mary's University School of Graduate Studies Institute of Agriculture and Development Studies. MSc. Thesis. Addis Ababa.

Nia, Rosiana et.al. (2017). The Level of Comparative Advantages of World main Coffee producers

Paul, R. Krugman, Maurice Obstfeld, and Marc J. Melitz. (2012). International Economics Theory \& Policy; Ninth Edition

Phillips, P., and P. Perron, (1988). Testing for a Unit Root in Time Series Regression. Biometrica, 75: 335-346.

Porter, M.E. (1990). The Competitive Advantage of Nations, Harvard Business Review

Samuel, (2012), Determinants of agricultural export in Ethiopia.

Hussain, et.al. (2020). Determinants of export supply in Pakistan: A sector wise disaggregated analysis. https://doi.org/10.1080/23322039.2020.1732072

Sawore, A. (2015). Determinants of Export Trade in Econometric Study with Special Reference to Ethiopia. International Journal of Science and Research (IJSR) ISSN (Online): 2319-7064 Index Copernicus Value (2015): 78.96 | Impact Factor 6.391.

Siti, et.al. (2017). Determinants of Service Export in Selected Developing Asian Countries. International Journal of Business and Society, Vol. 18 No1, 113-132

Sohail, Ayyaz et.al. (2019). Competitiveness in Mango Trade: a Comparative Analysis between Pakistan and other Mango Exporting Nations. International Journal of Food and Agricultural Economics Vol. 7, No. 4, 2019, pp. 341-349

Soressa, (2013): Exports, domestic demand and economic growth in Ethiopia: Granger causality analysis. Journal of Economics and International Finance. Vol. 5(9), pp. 357-372: DOI: 10.5897/JEIF2013.0537; http://www.academicjournals.org/JEIF

Sri, Tjondro W. et.al. (2018). Competitiveness Analysis of Robusta Coffee in East Java, Indonesia. Academy of Strategic Management Journal Volume 17, Issue 6, 2018

Sukati, M. (2016). COMESA Revealed Comparative Advantage in Common Agricultural Commodities. Online at https://mpra.ub.uni muenchen.de/69989/MPRA Paper No. 69989, posted 13 Mar 2016 15:01 UTC

Tadese,G. (2015). Determinants of Coffee Export Performance in Ethiopia: www.iiste.org.

Teshome, K. (2009). Determinants of coffee export equation in Ethiopia. African Economic Research Consortium, Nairobi, November 2009

Tigist, A. (2018). The Determinants of Export Performance in Ethiopia: a Panel Data Analysis. Master's Thesis, Addis Ababa University: Addis Ababa, Ethiopia

UNCTAD, (2018). East African Community regional integration: Trade and gender implications. Technical report, United Nations Conference on Trade and Development, Geneva, Switzerland.

Vilani, Sachitra. (n.d). Determinants of Export Competitiveness: An Empirical Study of Tea Industry in Sri Lanka

World Bank, (2014). Strengthening Export Performance through Improved Competitiveness 3RD Ethiopia Economic Update

WTO, (2017), Trade Policy Review

Yeshineh, Alekaw Kebede. (2016). Determinants and Potentials of Foreign Trade in Ethiopia: A Gravity Model Analysis Online at https://mpra.ub.uni-muenchen.de/74509/

Yishak, T. (2009). Determinants of Ethiopia's Export Performance: A Gravity Model Analysis, Trade and Development Discussion Paper No. 01/2009, bkp Development Research and Consulting, Germany

Zekarias, Bassa \& Degye, Goshu. (2019). Determinants of Coffee Export in Ethiopia: An Application of CoIntegration and Vector Error Correction Approach Agricultural and Resource Economics: International Scientific E-Journal www.are-journal.com JEL: Q00, Q10, Q13, Q17

Zewdu, Bedasa \& Minyahil, Alemu, (2017). Economic Growth Nexus Trade Liberalization in Ethiopia: Evidence from the Johnson's Multivariate Co-integration Analysis. International Journal of Latest Research in Engineering. 


\section{Appendices}

Table A:Mult-collinearity Test :Intercorrelation among Variables in the Model

\begin{tabular}{|c|c|c|c|c|c|c|c|c|}
\hline Variables & 1 & 2 & 3 & 4 & 5 & 6 & 7 & 8 \\
\hline LnFDI & 1 & 0.88 & 0.8117 & 0.8604 & 0.5447 & 0.8355 & -0.6995 & 0.381 \\
\hline LnRER & 0.88 & 1 & 0.7473 & 0.8183 & 0.5177 & 0.8892 & -0.5966 & 0.2886 \\
\hline LnTCE & 0.8117 & 0.7473 & 1 & 0.8237 & 0.4481 & 0.7602 & -0.5772 & 0.4058 \\
\hline LnDpd & 0.8604 & 0.8183 & 0.8237 & 1 & 0.4804 & 0.8679 & -0.5865 & 0.3361 \\
\hline$L n W p r$ & 0.5447 & 0.5177 & 0.4481 & 0.4804 & 1 & 0.4192 & 0.0855 & 0.1038 \\
\hline LnWpd & 0.8355 & 0.8892 & 0.7602 & 0.8679 & 0.4192 & 1 & -0.7433 & 0.357 \\
\hline$C p r$ & -0.6995 & -0.596 & -0.5772 & -0.5865 & 0.0855 & -0.7433 & 1 & -0.354 \\
\hline$R C A$ & 0.381 & 0.2886 & 0.4058 & 0.3361 & 0.1038 & 0.357 & -0.3542 & 1 \\
\hline
\end{tabular}

\section{Model stability test}
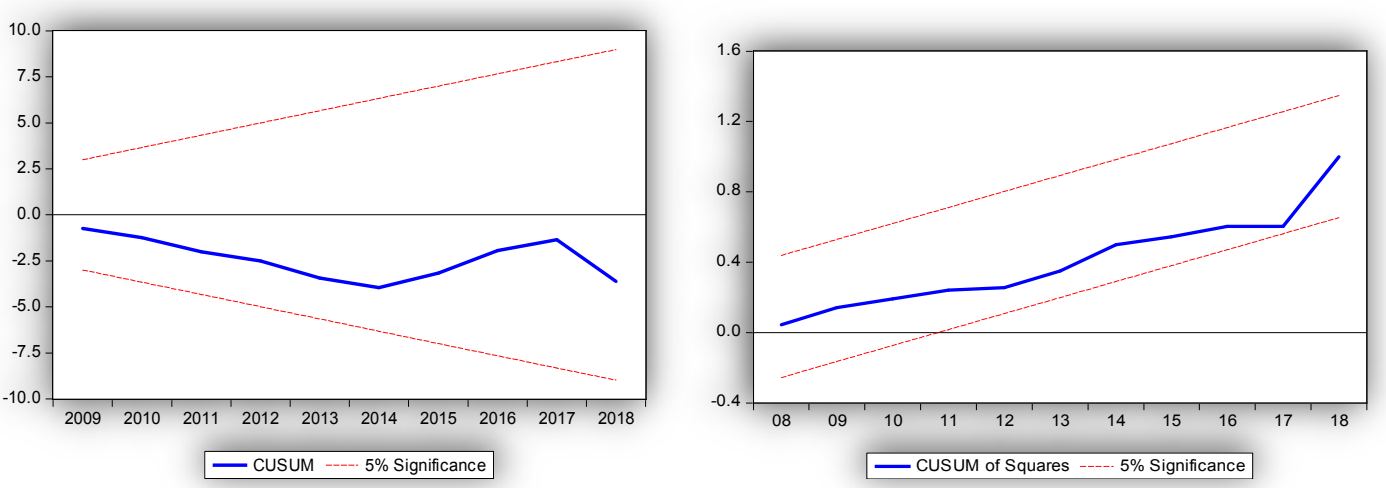

Figure A: Recursive residuals (CUSUM) and recursive residuals square (CUSUM SQUARE) performance. Source: own computation (2020) 